\title{
Editorials
}

\section{Is Dual Antiplatelet Therapy Necessary in Transcatheter Aortic Valve Implantation?}

\author{
Atsushi Oguri, ${ }^{1} \mathrm{MD}$ and Jiro ANDo, ${ }^{1} \mathrm{MD}$
}

$\mathrm{T}$

The use of transcatheter aortic valve implantation (TAVI) for aortic valve stenosis became possible in Japan in 2013. In the past two years, TAVI has been performed in more than 2,000 cases; gradual introduction of the practice has initially produced favorable results. According to the Japan OCEAN-TAVI registry, the 30-day mortality rate is $1.9 \%$, which is reportedly low in comparison to the rates in the United States and Europe. ${ }^{1)}$

TAVI provides a hope for cure in patients with severe aortic valve stenosis. However, patients undergoing TAVI may be at high risk for bleeding and stroke. The incidence of these 2 complications is at least 10-fold higher for TAVI than for percutaneous coronary interventions (PCI): the 30-day risk of major stroke $(\sim 3.5 \%)$ and major bleeding/vascular complications $(\sim 10 \%)$ indicate a considerable challenge for balancing the risks of embolic and bleeding events in these high-risk patients $^{2-18)}$ (Table I). When TAVI is used for treating embolism, it is a common practice to use dual antiplatelet therapy (DAPT) for 3 to 6 months ${ }^{17)}$ (Table II). However, this practice is mainly based on experience, and no analysis has been conducted yet through a large scale RCT. In particular, since Japanese patients often develop bleeding complications, it is likely that employing DAPT across the board may not be appropriate. The occurrence of serious bleeding events negatively impacts survival after TAVI and the risk of short and mid-term mortality. $^{19)}$

\begin{tabular}{l} 
Article p.190 \\
\hline Bleeding complications in Japanese patients are believed \\
to occur mainly due to their higher prevalence of metabolic ab- \\
normalities and smaller physique. Watanabe, et al reported that \\
one third of the patients undergoing TAVI responded well to \\
clopidogrel. ${ }^{20)}$ There is a high incidence of bleeding complica- \\
tions and good responses among Japanese patients. Japanese \\
patients with CYP2C19-induced metabolism abnormalities \\
can be classified into poor metabolizers (PM, 19\%), intermedi- \\
ate metabolizers (IM, 44\%), and extensive metabolizers (EM, \\
$37 \%$ ). It is reported that $56 \%$ of Japanese patients have \\
CYP2C19-induced metabolism abnormalities. ${ }^{21)}$ Based on \\
these findings, Watanabe, et al pointed out that there is a risk \\
associated with administering DAPT to all TAVI patients. In a \\
meta-analysis to study whether P2Y12 reactivity units (PRU) \\
can predict the prognosis, 3059 patients undergoing PCI were \\
analyzed in 6 studies, and a significantly high incidence of \\
complications due to MI or stent thrombosis was reported for
\end{tabular}

patients with PRU $\geqq 230$. $^{20,22)}$ In the dual antiplatelet therapy with drug-eluting stents (ADAPT-DES) prospective study involving 8,582 PCI patients in 11 US and European hospitals, bleeding complications due to MI or ST were significantly higher in the high platelet reactivity group with PRU > 208, suggesting that personalized treatment based on PRU measurements may be effective. ${ }^{23)}$ On the other hand, in the ARCTIC trial prospective study with 2,440 PCI patients, or the GRAVITAS randomized trial prospective study with 2,214 PCI patients, no significant difference in prognosis could be attributed to PRU monitoring. ${ }^{24,25)}$ All these are PCI-based studies, and to date, no large-scale prospective study has been undertaken with TAVI; such a study is much needed.

Compared to Americans and Europeans, Japanese have smaller physiques, and exhibit a higher tendency to calcification of the valve annulus. There is a high risk of annulus rupture, and coronary artery disorders may be likely due to calcification of the valsalva sinus. Watanabe, et al reported that with narrow peripheral vasculature, vascular complications and the 30-day combined safety endpoint rate were significantly higher in the small body (body surface area $<1.75 \mathrm{~m}^{2}$ ) group $(13.0 \%$ versus $4.3 \%, P<0.01 ; 27.4 \%$ versus $18.3 \%, P=0.03$, respectively). ${ }^{20,26)}$ In cases of vascular complications or conversion to surgical aortic valve replacement (SAVR), oral administration of DAPT increases the bleeding risk. Since Japanese people have a smaller physique, a more discreet use of antiplatelet agents is called for.

Among the TAVI patients, approximately one third had chronic atrial fibrillation (AF) and were undergoing anticoagulation therapy. AF patients often take warfarin, and there is no predetermined antiplatelet therapy for TAVI patients undergoing anticoagulant therapy. Aspirin and warfarin or warfarin alone may be the most effective and safe approach to anticoagulation in post-TAVI patients with underlying AF. In the WOEST (What Is the Optimal Antiplatelet and Anticoagulant Therapy in Patients With Oral Anticoagulation and Coronary Stenting?) trial, clopidogrel with warfarin was superior to triple therapy in patients with atrial fibrillation undergoing drug-eluting stent placement (including a striking decrease in all-cause mortality associated with clopidogrel/warfarin [hazard ratio: 0.39 ; $95 \%$ CI: 0.16 to 0.93$]) .^{27,28)}$ Further large-scale prospective studies are required before we can confidently recommend a similar protocol for TAVI as well.

Since the bleeding risk is high for TAVI in Japanese patients because of the high prevalence of CYP2C19-induced

From the ${ }^{1}$ Department of Cardiovascular Medicine, Graduate School of Medicine, The University of Tokyo, Tokyo, Japan.

Address for correspondence: Atsushi Oguri, MD, Department of Cardiovascular Medicine, Graduate School of Medicine, The University of Tokyo, 7-3-1 Hongo, Bunkyo-ku, Tokyo 113-8655, Japan. E-mail: ogurimd@gmail.com

Received for publication February 6, 2016. Accepted February 6, 2016.

Released in advance online on J-STAGE March 11, 2016.

All rights reserved by the International Heart Journal Association. 
Table I. Ischemic and Bleeding Outcomes at 30 Days and 1 Year in Large TAVI Registries

\begin{tabular}{|c|c|c|c|c|c|c|c|c|c|c|}
\hline & $\begin{array}{c}\text { European }^{8)} \\
(n=646)\end{array}$ & $\begin{array}{c}\text { Canadian }^{5)} \\
(n=339)\end{array}$ & $\begin{array}{l}\text { SOURCE }^{6,7)} \\
(n=1,038)\end{array}$ & $\begin{array}{l}\text { Italian }^{24)} \\
(n=663)\end{array}$ & $\begin{array}{c}\text { FRANCE }^{9)} \\
(n=244)\end{array}$ & $\begin{array}{l}\text { Belgian }^{11)} \\
(n=328)\end{array}$ & $\begin{array}{l}\text { FRANCE-2 }^{16} \\
(n=3,195)\end{array}$ & $\begin{array}{l}\text { SOURCE XT }{ }^{(3)} \\
(n=2,706)\end{array}$ & $\begin{array}{l}\text { ADVANCE }^{14)} \\
(n=1,015)\end{array}$ & $\begin{array}{c}\text { ANZ }^{15)} \\
(n=428)\end{array}$ \\
\hline \multicolumn{11}{|l|}{30 days } \\
\hline Vascular complications & - & $13.0 \%$ & $12.8 \%$ & - & $7.3 \%$ & - & - & - & - & $12.6 \%$ \\
\hline Major & - & - & $7.0 \%$ & $2.0 \%$ & - & - & - & $6.0 \%$ & $10.7 \%$ & $4.0 \%$ \\
\hline Minor & - & - & $5.5 \%$ & - & - & - & - & - & - & $8.9 \%$ \\
\hline Bleeding & - & - & - & - & - & - & - & - & - & $23.1 \%$ \\
\hline Life-threatening/disabling & - & - & - & - & - & - & - & - & $4.0 \%$ & $4.7 \%$ \\
\hline Major & - & - & - & - & - & - & - & $7.2 \%$ & $9.7 \%$ & $8.9 \%$ \\
\hline Minor & - & - & - & - & - & - & - & - & - & $12.9 \%$ \\
\hline Stroke & $1.9 \%$ & $2.3 \%$ & $2.5 \%$ & $1.2 \%$ & $3.6 \%$ & $5.0 \%$ & $3.4 \%$ & $2.2 \%$ & $2.9 \%$ & $3.6 \%$ \\
\hline Major & - & - & - & - & - & - & $1.9 \%$ & - & $1.2 \%$ & - \\
\hline Minor & - & - & - & - & - & - & $1.5 \%$ & - & $1.7 \%$ & - \\
\hline \multicolumn{11}{|l|}{1 year } \\
\hline Vascular complications & - & - & - & - & - & - & - & - & - & - \\
\hline Major & - & - & - & - & - & - & $4.7 \%$ & - & - & - \\
\hline Minor & - & - & - & - & - & - & $5.0 \%$ & - & - & - \\
\hline Bleeding & - & - & - & - & - & - & $13.1 \%$ & - & - & - \\
\hline Life-threatening/disabling & - & - & - & - & - & - & $1.2 \%$ & - & - & - \\
\hline Major & - & - & - & $3.2 \%$ & - & - & $4.5 \%$ & - & - & - \\
\hline Minor & - & - & - & - & - & - & $7.4 \%$ & - & - & - \\
\hline Stroke & - & - & $4.5 \%$ & $2.5 \%$ & - & - & $4.1 \%$ & - & - & $5.3 \%$ \\
\hline
\end{tabular}

ANZ indicates Australia-New Zealand; FRANCE, French Aortic National CoreValve and Edwards Registry; SOURCE, SAPIEN Aortic Bioprosthesis European Outcome Registry; and TAVI, transcatheter aortic valve implantation. (Rodés-Cabau J, et al. J Am Coll Cardiol 2013; 62: 2349-59. ${ }^{18)}$ )

Table II. Current Recommendations for Antithrombotic Agents and Strategies for TAVI

\begin{tabular}{|c|c|c|c|}
\hline & PARTNER Trial ${ }^{17,18)}$ & ACC/STS Recommendations ${ }^{30)}$ & CCS Statement $^{31)}$ \\
\hline Pre-procedural & $\begin{array}{l}\text { Aspirin } 80 \mathrm{mg} \\
\text { Clopidogrel } 300 \mathrm{mg}\end{array}$ & - & - \\
\hline Procedural & $\begin{array}{l}\text { Unfractionated heparin } \\
\text { Goal ACT: } 250 \mathrm{~s} \\
\text { Reversal with protamine optional } \\
\text { Bivalirudin - not allowed? }\end{array}$ & $\begin{array}{l}\text { Unfrctionated heparin } \\
\text { Goal ACT: } 300 \mathrm{~s} \\
\text { Reversal with protamine recommended } \\
\text { Bivalirudin - not mentioned }\end{array}$ & - \\
\hline $\begin{array}{l}\text { Post-procedural } \\
\text { (first } 30 \text { days) }\end{array}$ & $\begin{array}{l}\text { Aspirin } 81 \mathrm{mg} / \text { day indefinitely }+ \\
\text { Clopidogrel } 75 \mathrm{mg} / \text { day } \times 90 \text { days }\end{array}$ & $\begin{array}{l}\text { Aspirin } 81 \mathrm{mg} / \text { day indefinitely }+ \\
\text { Clopidogrel } 75 \mathrm{vmg} / \text { day } \times 3-6 \text { months } \\
\text { If warfarin indicated }(\mathrm{AF}) \text {, then no } \\
\text { clopidogrel }\end{array}$ & $\begin{array}{l}\text { Indefinite low-dose aspirin generally } \\
\text { recommended }+ \text { Thienopyridine } \times 1-3 \text { months. } \\
\text { If oral anticoagulant indicated (AF), avoid triple } \\
\text { therapy unless definite indication exists }\end{array}$ \\
\hline
\end{tabular}

ACC indicates American College of Cardiology; ACT, activated clotting time; AF, atrial fibrillation; CCS, Canadian Cardiovascular Society; STS, The Society for Thoracic Surgeons; and TAVI, transcatheter aortic valve implantation. (Rodés-Cabau J, et al. J Am Coll Cardiol 2013; 62: 2349-59. ${ }^{18}$ )

metabolic abnormalities and their small physique, rather than blindly applying the results of Western studies, the accumulation of Japanese-specific research data is needed. In addition, since TAVI patients develop complications because approximately one third of them have AF and $60 \%$ have coronary artery disorders, ${ }^{29)}$ studies on a case-by-case basis are required on therapy consisting of combinations of anticoagulant, aspirin, and thienopyridine, depending on varying conditions such as post-PCI, complications due to AF, and different time periods after stent placement. Instead of a standardized approach to decide the DAPT period, it is considered likely that personalized medicine that takes into account gene polymorphism based on PRU measurements from VerifyNow may be more effective.

\section{Disclosure}

Conflicts of interest: The authors declare there are no conflicts of interest.

\section{REFERENCES}

1. Inohara T, Hayashida $\mathrm{K}$, Watanabe $\mathrm{Y}$, et al. Streamlining the learning process for TAVI: Insight from a comparative analysis of the OCEAN-TAVI and the massy registries. Catheter Cardiovasc Interv 2015 (in press)

2. Kodali SK, Williams MR, Smith CR, et al. Two-year outcomes after transcatheter or surgical aortic-valve replacement. N Engl J Med 2012; 366: 1686-95.

3. Rodés-Cabau J, Webb JG, Cheung A, et al. Transcatheter aortic valve implantation for the treatment of severe symptomatic aortic stenosis in patients at very high or prohibitive surgical risk: acute 
and late outcomes of the multicenter Canadian experience. J Am Coll Cardiol 2010; 55: 1080-90.

4. Thomas M, Schymik G, Walther T, et al. Thirty-day results of the SAPIEN aortic Bioprosthesis European Outcome (SOURCE) Registry: A European registry of transcatheter aortic valve implantation using the Edwards SAPIEN valve. Circulation 2010; 122: 62-9.

5. Thomas M, Schymik G, Walther T, et al. One-year outcomes of cohort 1 in the Edwards SAPIEN Aortic Bioprosthesis European Outcome (SOURCE) registry: the European registry of transcatheter aortic valve implantation using the Edwards SAPIEN valve. Circulation 2011; 124: 425-33.

6. Piazza N, Grube E, Gerckens U, et al. Procedural and 30-day outcomes following transcatheter aortic valve implantation using the third generation $(18 \mathrm{Fr})$ corevalve revalving system: results from the multicentre, expanded evaluation registry 1-year following CE mark approval. EuroIntervention 2008; 4: 242-9.

7. Eltchaninoff $\mathrm{H}$, Prat A, Gilard M, et al. Transcatheter aortic valve implantation: early results of the FRANCE (French Aortic National CoreValve and Edwards) registry. Eur Heart J 2011; 32: 191-7.

8. Zahn R, Gerckens U, Grube E, et al. Transcatheter aortic valve implantation: first results from a multi-centre real-world registry. Eur Heart J 2011; 32: 198-204.

9. Bosmans JM, Kefer J, De Bruyne B, et al. Procedural, 30-day and one year outcome following CoreValve or Edwards transcatheter aortic valve implantation: results of the Belgian national registry. Interact Cardiovasc Thorac Surg 2011; 12: $762-7$.

10. Moat NE, Ludman P, De Belder MA, et al. Long-term outcomes after transcatheter aortic valve implantation in high-risk patients with severe aortic stenosis: the U.K. TAVI (United Kingdom Transcatheter Aortic Valve Implantation) registry. J Am Coll Cardiol 2011; 58: 2130-8.

11. Schymik G, Lefèvre T, Bartorelli AL, et al. European experience with the second-generation Edwards SAPIEN XT transcatheter heart valve in patients with severe aortic stenosis: 1-year outcomes from the SOURCE XT Registry. JACC Cardiovasc Interv 2015; 8: 657-69.

12. Linke A, Gerckens U, Wenaweser P, et al. Treatment of high risk aortic stenosis patients with transcatheter Medtronic CoreValve implantation: results from the international multicenter ADVANCE study. J Am Coll Cardiol 2012; 59: E8.

13. Meredith IT, Walton A, Walters DL, et al. Mid-term outcomes in patients following transcatheter aortic valve implantation in the CoreValve Australia and New Zealand Study. Heart Lung Circ 2015; 24: 281-90.

14. Gilard M, Eltchaninoff H, Iung B, et al. Registry of transcatheter aortic-valve implantation in high-risk patients. N Engl J Med 2012; 366: 1705-15.

15. Leon MB, Smith CR, Mack M, et al. Transcatheter aortic-valve implantation for aortic stenosis in patients who cannot undergo surgery. N Engl J Med 2010; 363: 1597-607.

16. Smith CR, Leon MB, Mack MJ, et al. Transcatheter versus surgical aortic-valve replacement in high-risk patients. N Engl JMed 2011; 364: 2187-98.
17. Masson J-B, Kovac J, Schuler G, et al. Transcatheter aortic valve implantation: review of the nature, management, and avoidance of procedural complications. JACC Cardiovasc Interv 2009; 2: 81120. (Review)

18. Rodés-Cabau J, Dauerman HL, Cohen MG, et al. Antithrombotic treatment in transcatheter aortic valve implantation: insights for cerebrovascular and bleeding events. J Am Coll Cardiol 2013; 62: 2349-59. (Review)

19. Kochman J, Rymuza B, Huczek Z, et al. Incidence, predictors and impact of severe periprocedural bleeding according to VARC-2 criteria on 1-year clinical outcomes in patients after transcatheter aortic valve implantation. Int Heart J 2016; 57: 35-40.

20. Watababe Y, Kozuma K, Ishikawa S, Hosogoe N, Isshiki T. Hyperresponse to clopidogrel in Japanese patients undergoing transcatheter aortic valve implantation. Int Heart J 2016; 57; 190-7.

21. Yamamoto K, Hokimoto S, Chitose T, et al. Impact of CYP2C19 polymorphism on residual platelet reactivity in patients with coronary heart disease during antiplatelet therapy. J Cardiol 2011; 57: 194-201.

22. Brar SS, ten Berg J, Marcucci R, et al. Impact of platelet reactivity on clinical outcomes after percutaneous coronary intervention. A collaborative meta-analysis of individual participant data. J Am Coll Cardiol 2011; 58: 1945-54.

23. Stone GW, Witzenbichler B, Weisz G, et al. Platelet reactivity and clinical outcomes after coronary artery implantation of drug-eluting stents (ADAPT-DES): a prospective multicentre registry study. Lancet 2013; 382: 614-23.

24. Collet JP, Cuisset T, Rangé G, et al. Bedside monitoring to adjust antiplatelet therapy for coronary stenting. N Engl J Med 2012; 367: 2100-9.

25. Price MJ, Berger PB, Teirstein PS, et al. Standard- vs high-dose clopidogrel based on platelet function testing after percutaneous coronary intervention: the GRAVITAS randomized trial. JAMA 2011; 305: 1097-105.

26. Watanabe Y, Hayashida K, Lefèvre T, et al. Transcatheter aortic valve implantation in patients of small body size. Catheter Cardiovasc Interv 2014; 84: 272-80.

27. Dewilde W, Berg JT. Design and rationale of the WOEST trial: What Is the Optimal Antiplatelet and Anticoagulant Therapy in Patients With Oral Anticoagulation and Coronary Stenting (WOEST). Am Heart J 2009; 158: 713-8.

28. Dewilde WJ, Oirbans T, Verheugt FW, et al. Use of clopidogrel with or without aspirin in patients taking oral anticoagulant therapy and undergoing percutaneous coronary intervention: an openlabel, randomised, controlled trial. Lancet 2013; 381: 1107-15.

29. Stefanini GG1, Stortecky S, Wenaweser P, Windecker S. Coronary artery disease in patients undergoing TAVI: why, what, when and how to treat. EuroIntervention 2014; 10: U69-75.

30. Holmes DR Jr, Mack MJ, Kaul S, et al. 2012 ACCF/AATS/SCAI/ STS expert consensus document on transcatheter aortic valve replacement. J Am Coll Cardiol 2012; 59: 1200-54. (Review)

31. Webb J, Rodés-Cabau J, Fremes S, et al. Transcatheter aortic valve implantation: a Canadian Cardiovascular Society position statement. Can J Cardiol 2012; 28: 520-8. (Review) 